\title{
EHMTI-0322. Effect of cervical epidural 10khz spinal cord stimulation on patients suffering from chronic, medically-refractory migraine
}

 \\ From 4th European Headache and Migraine Trust International Congress: EHMTIC 2014 \\ Copenhagen, Denmark. 18-21 September 2014
}

A significant minority of chronic migraine $(\mathrm{CM})$ patients do not respond to conventional medical treatment. Occipital nerve stimulation is a therapeutic option for refractory $\mathrm{CM}(\mathrm{rCM})$. However, randomized studies have failed to demonstrate efficacy. Cervical $10 \mathrm{kHz}$ spinal cord stimulation $(10 \mathrm{kHz}-\mathrm{SCS})$ may provide a superior alternative to occipital stimulation. We report the preliminary results of a prospective, open-label, feasibility study to assess safety and tolerability cervical $10 \mathrm{kHz}-\mathrm{SCS}$ in $\mathrm{rCM}$ patients.

The study had EC approval and the subjects gave informed consent. Included subjects were diagnosed with $\mathrm{CM}$ by an experienced headache specialist according to IHS guidelines, were refractory to medical treatments as defined by the Refractory Headache Special Interest Section of the AHS, and had failed Botox treatment. Medication Overuse headache was not excluded.

Patients underwent a $10 \mathrm{kHz}$ SCS-trial followed by a permanent implant if a significant reduction in headache intensity/episodes was reported during the trial. One or two epidural leads were used to cover the $\mathrm{C} 2-\mathrm{C} 4$.

At 6 months 7 out of 14 patients reported > 30\% reduction in headache days. The average headache days reduction from baseline was $6.9 \pm 7.3$ days $(\mathrm{p}=0.04)$, while the reduction in the responder group was $12.9 \pm$ 5.3 days $(p=0.001)$. Three patients developed IPG tenderness and one had a lead migration that required surgical revision.

Paresthesia-free cervical $10 \mathrm{kHz}-\mathrm{SCS}$ may be an effective therapeutic option for chronic migraineurs refractory to conventional medications and Botox treatment.

'Pain Management \& Neuromodulation Centre, Guy's \& St Thomas' NHS

Trust, London, UK

Full list of author information is available at the end of the article
No conflict of interest.

\section{Authors' details}

1Pain Management \& Neuromodulation Centre, Guy's \& St Thomas' NHS Trust, London, UK. 'Department of Clinical and Molecular Medicine, Sapienza University of Rome, Rome, Italy.

Published: 18 September 2014

doi:10.1186/1129-2377-15-S1-G22

Cite this article as: Palmisani et al:: EHMTI-0322. Effect of cervical epidural $10 \mathrm{khz}$ spinal cord stimulation on patients suffering from chronic, medically-refractory migraine. The Journal of Headache and Pain 2014 15(Suppl 1):G22.

Submit your manuscript to a SpringerOpen ${ }^{\odot}$ journal and benefit from:

- Convenient online submission

- Rigorous peer review

- Immediate publication on acceptance

- Open access: articles freely available online

- High visibility within the field

- Retaining the copyright to your article

Submit your next manuscript at $>$ springeropen.com

\section{SpringerOpen ${ }^{\circ}$}

(c) 2014 Palmisani et al; licensee Springer. This is an Open Access article distributed under the terms of the Creative Commons Attribution License (http://creativecommons.org/licenses/by/2.0), which permits unrestricted use, distribution, and reproduction in any medium, provided the original work is properly cited. 